Article

\title{
Loss of European Dry Heaths in NW Spain: A Case Study
}

\author{
Pablo Ramil Rego ${ }^{1}$, Manuel A. Rodríguez Guitián ${ }^{1}$, Hugo López Castro ${ }^{1}$, \\ Javier Ferreiro da Costa ${ }^{1, *}$ and Castor Muñoz Sobrino ${ }^{2}$
}

1 GI 1934-TB (Territorio, Biodiversidade), Instituto de Biodiversidade Agraria e Desenvolvemento Rural (IBADER), Universidade de Santiago, Campus de Lugo s/n, Lugo E-27002, Spain; E-Mails: ramil.rego@gmail.com (P.R.R.); manuelantonio.rodriguez@usc.es (M.A.R.G.); hugolopezcastro@gmail.com (H.L.C.)

2 Departamento de Bioloxía Vexetal e Ciencias do Solo, Facultade de Ciencias, Universidade de Vigo, Campus de Marcosende s/n, Vigo E-36310, Spain; E-Mail: bvcastor@uvigo.es

* Author to whom correspondence should be addressed; E-Mail: javier.ferreiro@usc.es; Tel.: +34-982-824-507; Fax: +34-982-824-508.

Received: 13 May 2013; in revised form: 21 June 2013 / Accepted: 16 July 2013 /

Published: 2 August 2013

\begin{abstract}
Natural habitats are continuing to deteriorate in Europe with an increasing number of wild species which are also seriously threatened. Consequently, a coherent European ecological network (Natura 2000) for conservation of natural habitats and the wild fauna and flora (Council Directive 92/43/EEC) was created. Even so, there is currently no standardized methodology for surveillance and assessment of habitats, a lack that it is particularly problematic for those habitats occupying large areas (heathlands, forests, dunes, wetlands) and which require a great deal of effort to be monitored. In this paper we evaluate the changes affecting the European dry heaths (Nat-2000 4030) from the SCI Os Ancares-O Courel (Galicia, NW Spain) during the past decade. High-resolution aerial imagery analyses and Geographic Information Systems (GIS) were used. Losses of more than 7,000 ha (20.3\%) of European dry heaths were computed during the 2003-2011 period in the SCI Os Ancares-O Courel, and also an increase of the degree of fragmentation was demonstrated for this habitat. Paradoxically, major impacts (afforestations, pasturelands) were financed by agri-environmental funds from the EU. Rather than promote biodiversity, these activities have provoked serious damages in this habitat of community interest, which is in complete opposition to the objectives of protection involved in the declaration of the SCI Os Ancares-O Courel.
\end{abstract}


Keywords: European dry heaths; habitat loss; fragmentation; Natura 2000; Council Directive 92/43/EEC; surveillance; monitoring; GIS; high-resolution images

\section{Introduction}

Heathlands are comprised of a few types of vegetation characterized by the dominance of the woody species Erica, Calluna and Daboecia, which are often accompanied by Ulex spp. Their European distribution mainly ranges from the mountains of the Atlantic countries, Central Europe, and the Mediterranean regions of Iberia. Heathlands have been essential elements in shaping the Iberian landscape, both on a small and large scale. According to some authors [1-4], the most varied European types of heaths are found in the coastal arc extending between Brittany (France) and Porto (Portugal).

Heathlands support a large number of plant, invertebrate, amphibians, reptiles, birds and mammals that are specialized, rare, declining, or restricted to this habitat [5-8]. Heathlands play an important role in maintaining the ecological connectivity between ecosystems [9], as they are interspersed and in contact with other types of natural habitats, such as grasslands, forests and wetlands. This connection is essential for the migration, dispersal and genetic exchange of wild species [10]. Despite their ecological values, heathland communities have been the subject of specific research throughout all their European ranges since the early twentieth century [11-21]. However, the area occupied by heathlands all over Europe has experienced an obvious reduction since the 19th century [22-30], which has led to further heathland loss and fragmentation. This problem was observed by the Council of Europe just before the first European regulations on conservation of habitats were promulgated [31].

Southwestern European heathlands, especially those located in the NW sector of the Iberian Peninsula (Spain), have also reduced their surface. In this territory, heathlands have been some of the key landscape elements for much of the last glacial cycle $(110,000-10,000$ BP). Here they only retreated when forest advanced during the Holocene climatic optimum [32-34]. After this, heathland experienced a re-expansion during the past 4,000 years due to the deforestation caused by the human activities, and particularly in the littoral and sublittoral areas of NW Iberia, where the landscape becomes strongly anthropized. However, its area of distribution notably declined during the past century due to the intensification of other agroforestry uses. Traditional uses like grazing, cutting or controlled burning have been lost, and actually they are no longer developed. Therefore, heathlands are being transformed into crop fields and pasturelands, or they are afforestated with exotic species. This process entails the loss of cultural diversity associated with heathland, which includes some traditional uses (grazing, manure), cultural landscapes, additional outputs (honey), or toponomy [35].

At present, the loss and fragmentation of habitats are considered the main threats to biodiversity worldwide [36-38]. This has led to the adoption of the Strategic Plan for Biodiversity 2011-2020, approved by the tenth session of the Convention on Biological Diversity (CBD) held in Nagoya (2010). The European Biodiversity Strategy to 2020 [39] is in line with the Strategic Plan for Biodiversity.

European Union legislation on protection of habitats is mainly articulated through the Council Directive 92/43/EEC of 21 May 1992 on the conservation of natural habitats and of wild fauna and flora. The aim of this directive is to contribute towards ensuring biodiversity through maintaining or 
restoring, at favorable conservation status, natural habitats and species of wild fauna and flora of European Community interest. To achieve this objective, the directive creates a coherent European ecological network of special areas of conservation, called "Natura 2000".

Annex I of Council Directive 92/43/EEC includes those natural habitat types of community interest whose conservation requires the designation of special areas of conservation (Natura 2000) in terms of habitats representation in the territory. Habitat type Nat-2000 4030 "European dry heaths" is listed in Annex I of the Council Directive 92/43/EEC. European dry heaths present a wide distribution in Europe (Figure 1), covering territories of the Atlantic, Alpine, Mediterranean, Continental and Boreal biogeographical regions. In NW Iberia, almost all the Natura 2000 sites include some representation, more or less extensive, of this natural habitat type of community interest [40,41].

Figure 1. Distribution of the habitat type European dry heaths (Nat-2000 4030) in the European Union. Source: European Environment Agency (2009).

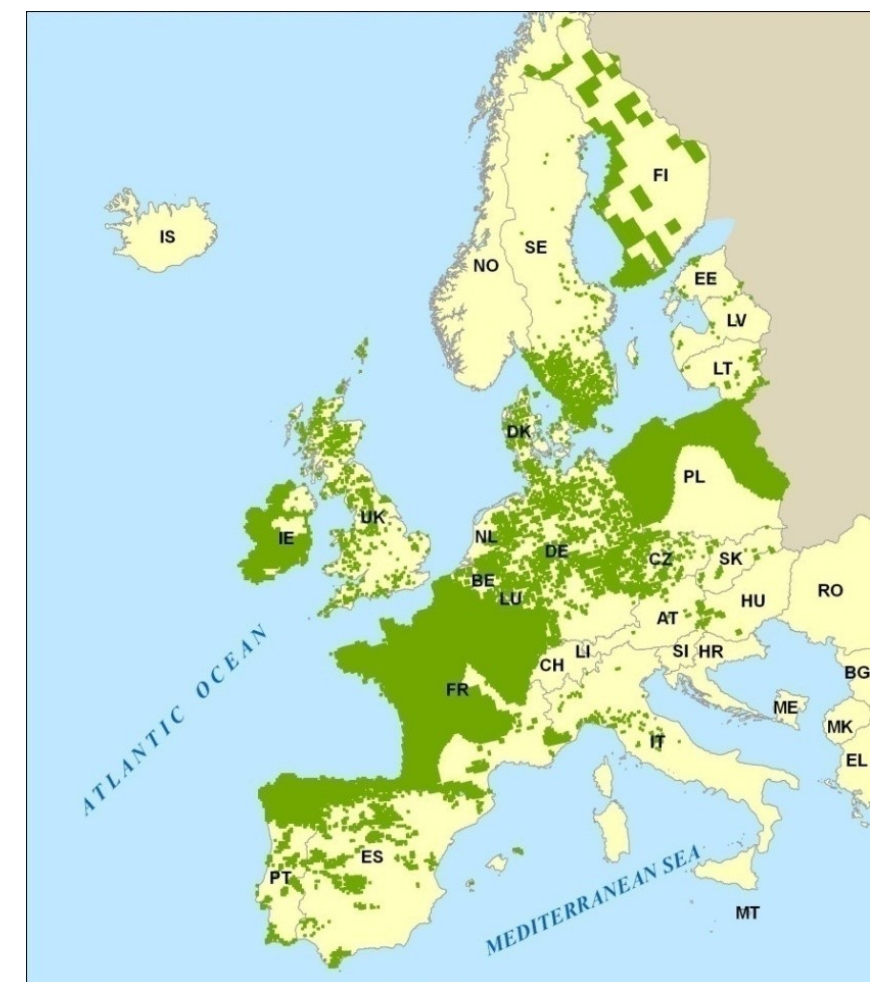

According to Council Directive 92/43/EEC, Member States shall undertake surveillance of the conservation status of the natural habitats and the species of community interest. A regular assessment (every six years) of conservation measures taken as well as evaluation of the impact of those measures on the conservation status of the natural habitats types and species of community interest shall be carried out.

However, Council Directive 92/43/EEC has not established a standardized methodology for both surveillance and assessment. In addition, monitoring the conservation status of habitat types that occupy large areas is particularly problematic because of the high cost in time and effort that they represent. This is more accentuated in some mountainous areas where large altitudinal and climatic differences exist and where the difficult orography avoids or complicates the access. In these cases, the 
positive cost/benefits balance of the use of remote imaging has determinated that it has emerged as a valuable tool in evaluating and monitoring the state of conservation of natural resources [42-44].

Following the provisions of Council Directive 92/43/EEC, this paper evaluates the European dry heaths loss occurred by human activity during the period 2003-2011 in a Natura 2000 Site of Community Importance located at the NW Iberia mountains. Furthermore, we will discuss the evaluation of the impact derived from replacement of traditional management for new intensive land uses, with special regard to maintaining or restoring the conservation status of European dry heaths habitat type along the period studied. The methodology employed has been the comparative analysis of aerial photographs by using Geographic Information Systems (GIS).

\section{Study Area}

This study was carried out at the Site of Community Importance (SCI) Os Ancares-O Courel (Nat-2000 Site Code ES1120001). This space is located in the Galician region, NW Spain (Figure 2). It was proposed by the regional government to form part of Natura 2000 network in 1999, and its final inclusion was approved in the European list of Sites of Community Importance for the Atlantic biogeographical region by Commission Decision 2004/813/EC, of 7 December 2004. The SCI Os Ancares-O Courel comprises an area of 102,438.9 ha. It is the largest Galician Natura 2000 site, representing $29.5 \%$ of the Galician SCIs land area and $28.8 \%$ of the Galician Natura 2000 network (SCIs and SPAs) land area.

Figure 2. Study area.

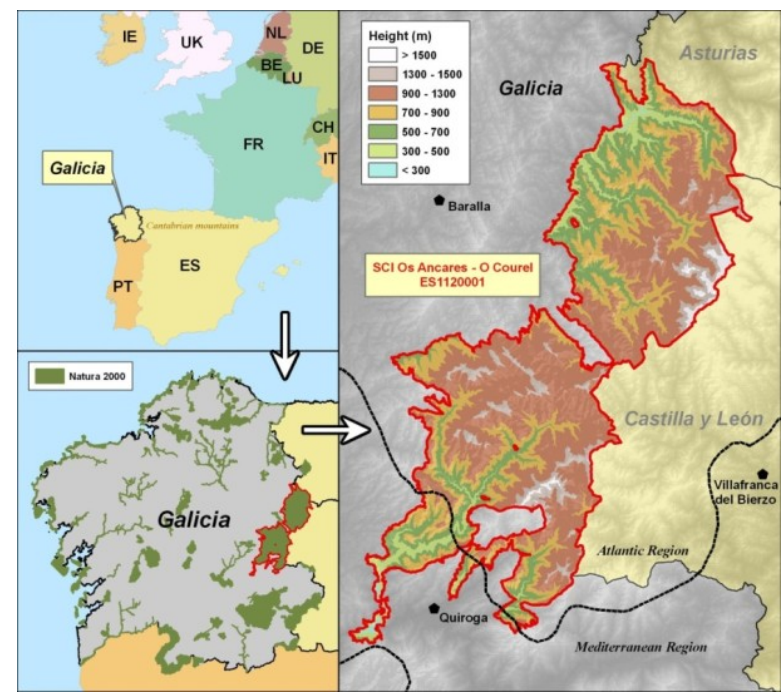

The SCI Os Ancares-O Courel extends at the western end of the Cantabrian Mountains, an area of rugged terrain with elevations ranging between 250 and 1,935 $\mathrm{m}$ (Figure 2). Because of this, climate is characterized by rainfall fluctuating between $700 \mathrm{~mm}$ in the lower areas and nearly $2,500 \mathrm{~mm}$ in the higher summits [45]. The annual thermometric regime is very much contrasted, with long harsher winters in the highlands. Annual average temperatures range from $4.6{ }^{\circ} \mathrm{C}$ in the higher areas, to $14.0^{\circ} \mathrm{C}$ in the most sheltered stations.

This SCI includes 37 habitat types of community interest, 12 of them being priority types. This means that more than a half of the habitat types of community interest described in Galicia are present 
in the SCI Os Ancares-O Courel [41]. The European dry heaths (Code Nat-2000 4030) are the best represented habitat type in this site, occupying 33.9\% of the SCI area (34,785.1 ha). Most of heathland patches are difficult to access in view that the relief is sharp and they usually appear on steep slopes and summits. According to biogeographical regions map of the European Environment Agency, most of the SCI belongs to the Eurosiberian biogeographical region but part of the southern corner is included in the Mediterranean region (Figure 2). Therefore, dry heaths are represented by a wide variety of plant communities included in the Atlantic, orophilous and xeric-Mediterranean subtypes.

Forest habitats are also well represented in terms of their variety and the covered areas. Woodlands occupy $22 \%$ of the SCI area, including 12 forest habitat types. The most notable types are the Galicio-Portuguese oak woods (Nat-2000 9230) with more than 12,700 ha (12.4\% of the SCI area), and the semi-natural Castanea sativa woods (Nat-2000 9260) with more than 8,000 ha (8\% of the SCI).

Agricultural land includes some areas that have significant values for biodiversity conservation, like the habitat types relative to the Mountain hay meadows (Nat-2000 6520), which cover more than 4,000 ha (4.2\% of the SCI area), and the Lowland hay meadows (Nat-2000 6510) covering about 900 ha $(0.9 \%$ of the SCI area).

\section{Methodology and Datasets}

Study area is included in the Natura 2000 network. Because of it, the method of changes analysis on the European dry heaths was chosen taking into account the Council Directive 92/43/EEC criteria about surveillance of the conservation status of the natural habitats and species, and their periodic evaluation. They were also consulted several previous experiences about the evaluation and monitoring of the conservation status of heathland that used remote sensing methodologies $[46,47]$. Due to the limitations imposed by the use of remote sensing data, the assessment of the conservation status of European dry heaths in the study area has been performed evaluating only the first two criteria listed in the Council Directive 92/43/EEC for considering the conservation status of a natural habitat as favorable: "its natural range and areas it covers within that range are stable or increasing"; and "the specific structure and functions which are necessary for its long-term maintenance exist and are likely to continue to exist for the foreseeable future." The third criterion: "assessment of the conservation status of its typical species of habitat" cannot be successfully performed with this method. Nevertheless, we decide to adopt this methodology due to the large area occupied by the European dry heaths in SCI Os Ancares-O Courel, and the spatial and temporal difficulties to get access to most of the patches due to the steep orography and the harsh winter climate, with frequent heavy snows.

The used images are color aerial high resolution orthoimagery (pixel size $25 \mathrm{~cm}$ ) for the years 2003 and 2011. They were provided by the Spanish government through the National Plan for Aerial Orthophoto. A high accuracy environmental map (1:5,000 scale) was made from the set of images of the year 2003 and using photo-interpretation techniques. In this map we have identified and georeferenced the habitat types, following Council Directive 92/43/EEC criteria [48]. Mapping units with dry heaths have been selected to be used in the comparative analysis of the second set of images, dating from 2011. 
During the process of comparison we have identified those significant changes by human activity (derived from replacement of traditional management for new intensive land uses) affecting both the surface occupied by heaths (area reduction) and its physiognomy (height and density of the scrub). So, in accordance with the criteria established by Council Directive 92/43/EEC for considering the conservation status of a natural habitat as favorable, the changes detected were classified into "dry heaths destruction" (areas in which there has been the elimination or conversion of heathlands) and "dry heaths degradation" (areas in which there has been an affection on the structure or functionality of the heathlands). Both natural habitat destruction and degradation contribute to the habitat loss phenomenon [49].

Delimitation of change areas has been made using the ArcGIS 10.1 software package [50]. The cause that has motivated the identified change areas was also determinated. They have been directly tested on the field on those changes that were doubtful, or where the cause was unknown. Figure 3 shows the types of activities identified as the cause of the physiognomic and structural changes detected in the analyzed tiles. There are no traditional uses between the identified causes.

Figure 3. Causes of destruction and degradation of the habitat type European dry heaths (Nat-2000 4030) identified in SCI Os Ancares-O Courel.

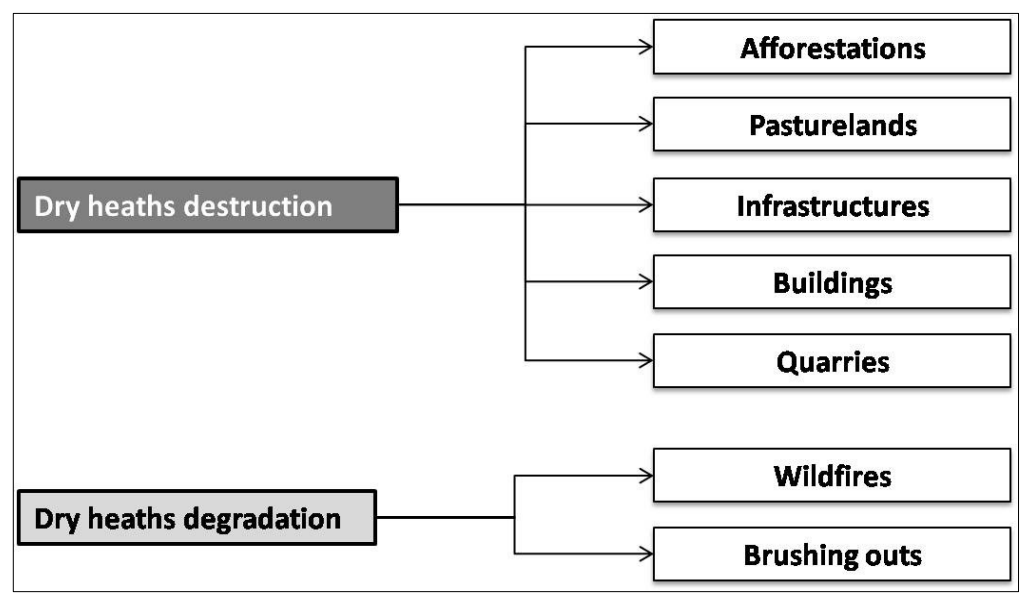

Among the changes included in "dry heaths destruction" category, we have identified five causes (Figure 4):

- Afforestations: in a first step these include removal of heath by using forestry brush slashers or shredders, followed by ripping soil in down-slope direction for in-row planting exotic tree species (Pinus spp., Eucalyptus spp, Pseudotsuga menziesii, Quercus rubra, Castanea $\times$ coudercii).

- Pasturelands: these comprise transformation of dry heathland by removal of heath and the preparation of topsoil by ploughing, milling and liming. Genetically selected strains of species of grazing interest of the genera Lolium, Dactylis and Trifolium are mainly sowed.

- Infrastructures: these include construction of roads, forest tracks, firebreaks and both power and data transmission lines, with destruction of the preexisting dry heath.

- Buildings: construction of buildings on the areas occupied by dry heaths.

- Quarries: this cause includes all actions related with opencast slate (opening the craters, tailings facility, access roads, settling basins, etc.), which it is a very common industrial activity in the area. 
Figure 4. Examples of destruction of the habitat type European dry heaths (Nat-2000 4030) in the study area during the period 2003-2011. (a) afforestations; (b) pasturelands; (c) infrastructures and buildings; (d) quarries.
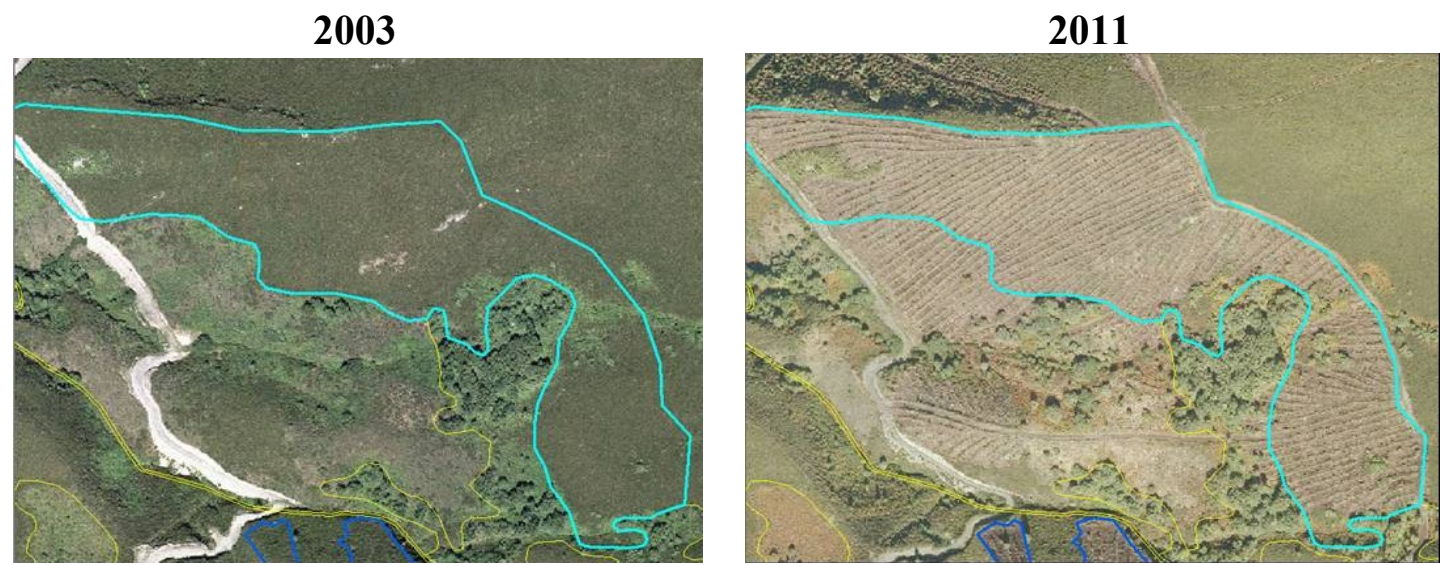

(a)
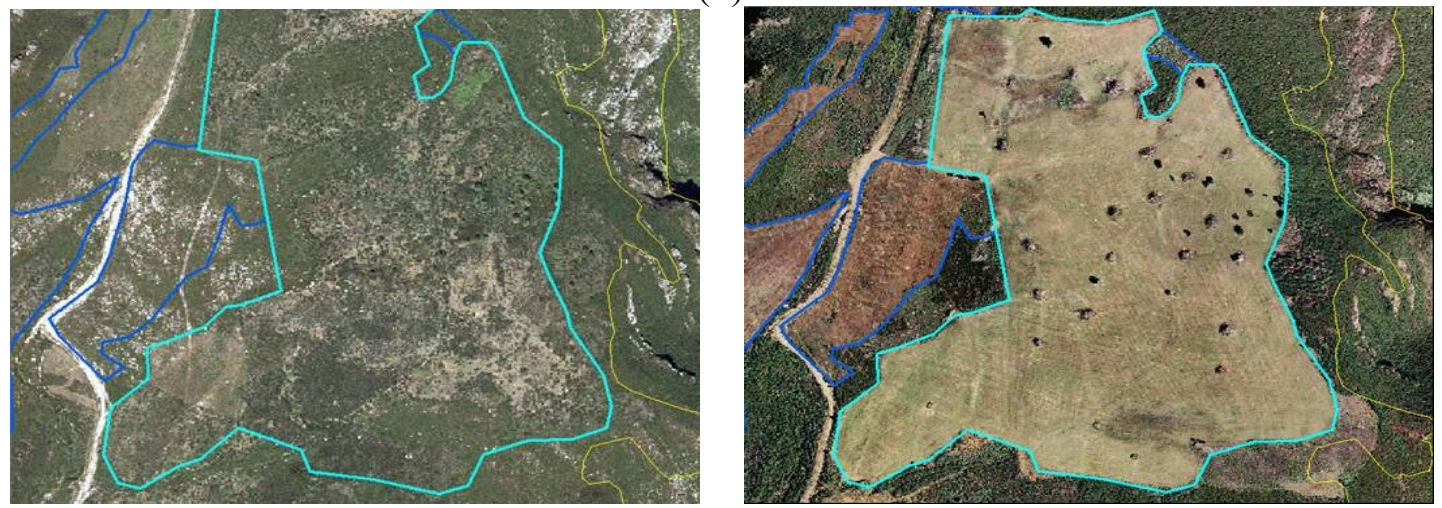

(b)
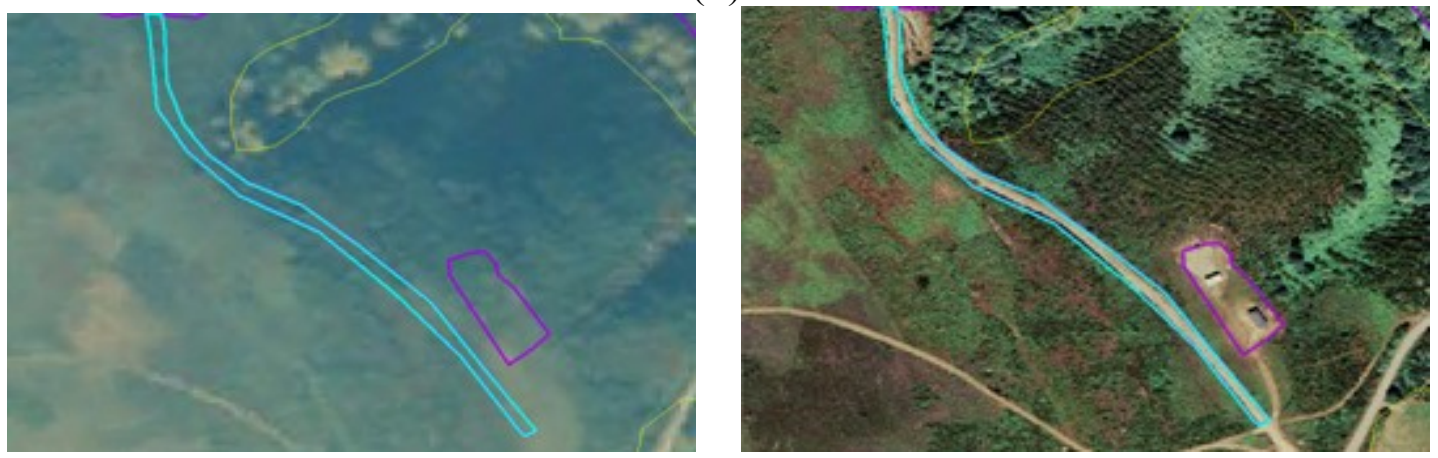

(c)
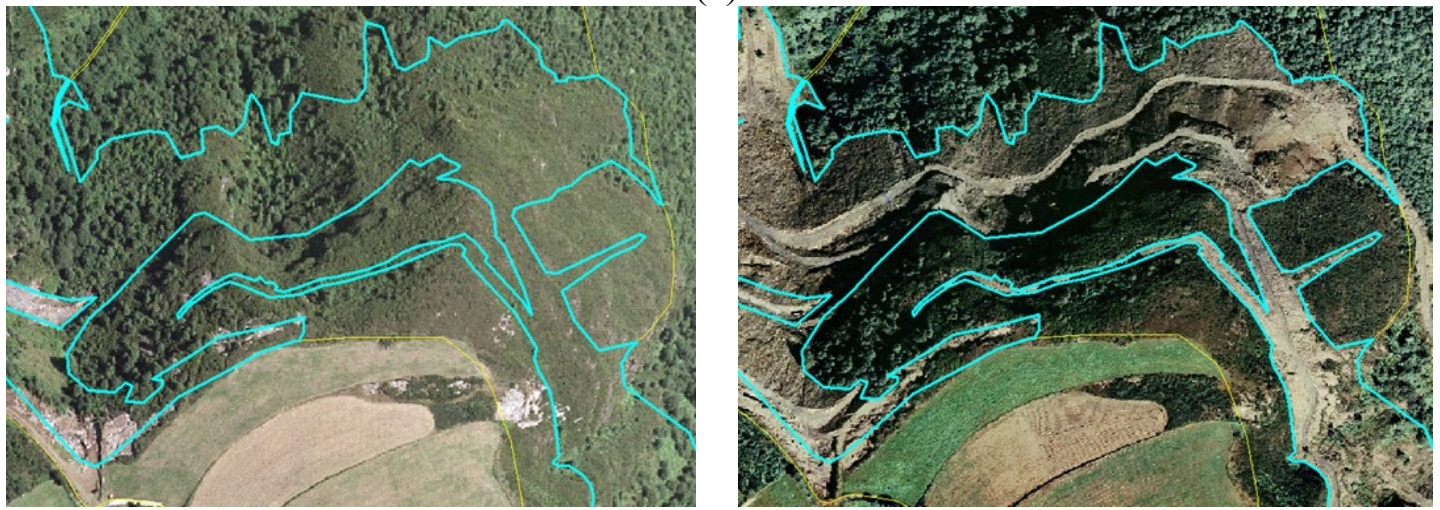

(d) 
We have differentiated the following causes of change included in "dry heaths degradation" (Figure 5):

- Wildfires: comprise those changes in structure and density of dry heath vegetation due to its combustion.

- Brushing outs: in these areas there has been a change in the structure and density of dry heath through slashing or shredding not followed by a tree plantation. These brushing outs have different purposes: feeding hunting species such as partridges (Alectoris rufa), to favor the blueberry bushes (Vaccinium myrtillus) which serves as food for brown bear (Ursus arctos).

The information obtained will be used to assess the effect of the changes detected on the degree of fragmentation of heathland by calculating the indicators most widely used [51]: number of patches, mean patch size, size of largest patch, total edge, and average nearest neighbor (ANN). Calculation of these indicators has been developed using the ArcGIS 10.1 software package [50].

Figure 5. Examples of degradation of the structure of the habitat type European dry heaths (Nat-2000 4030) in the study area during the period 2003-2011. (a) wildfires; (b) brushing outs.

2003

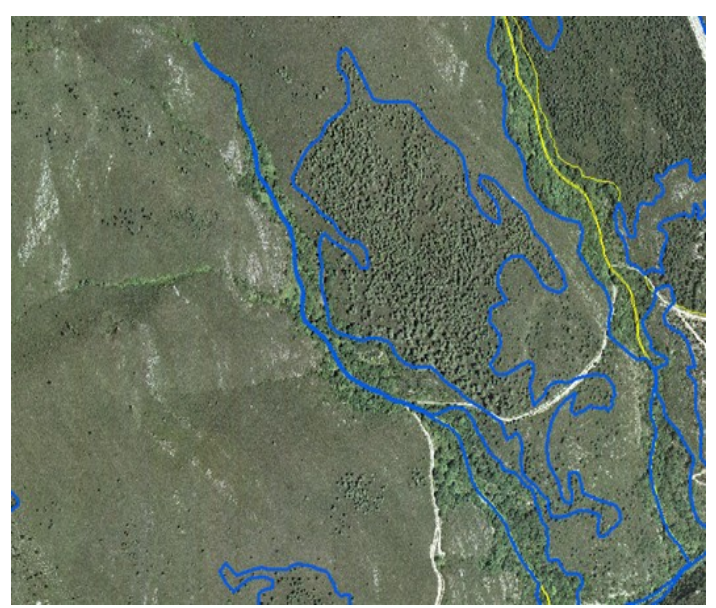

(a)

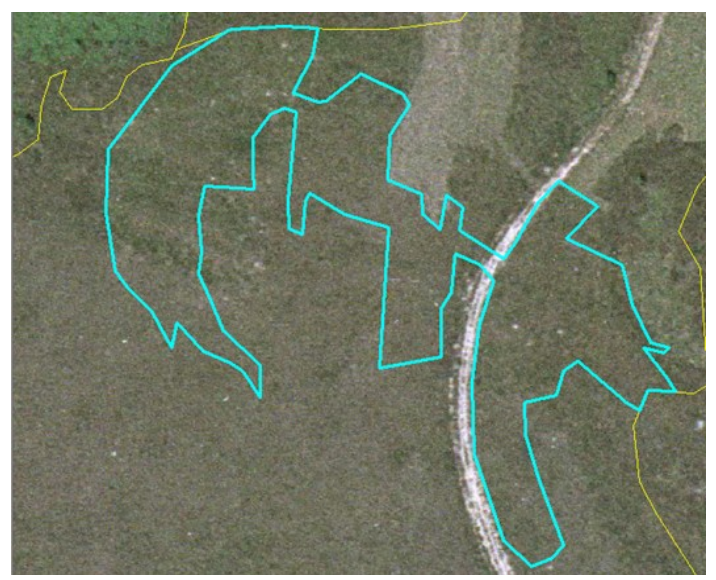

2011
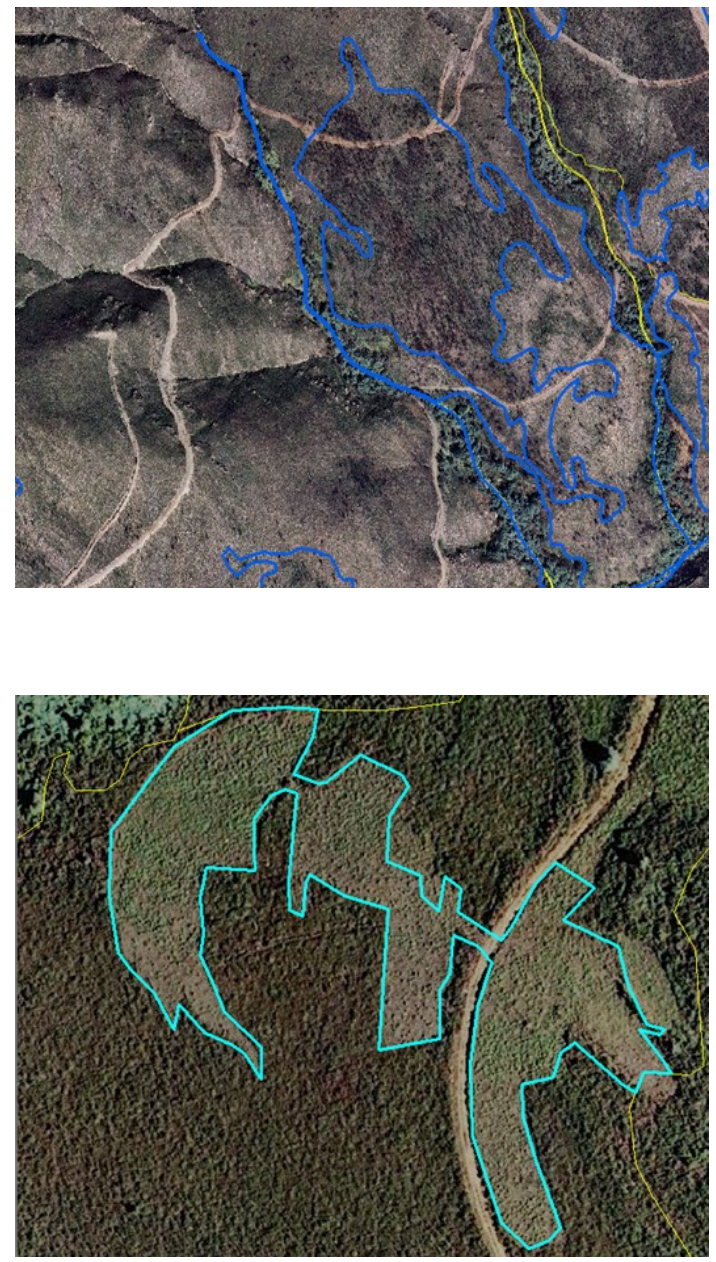

(b) 


\section{Results}

We have mapped 1,203 tiles with surface or structural characteristics changes of dry heath in the SCI Os Ancares-O Courel between 2003 and 2011 (Figure 6).

Figure 6. Destruction and degradation areas of dry heaths mapped in the SCI Os Ancares-O Courel during the period 2003-2011.

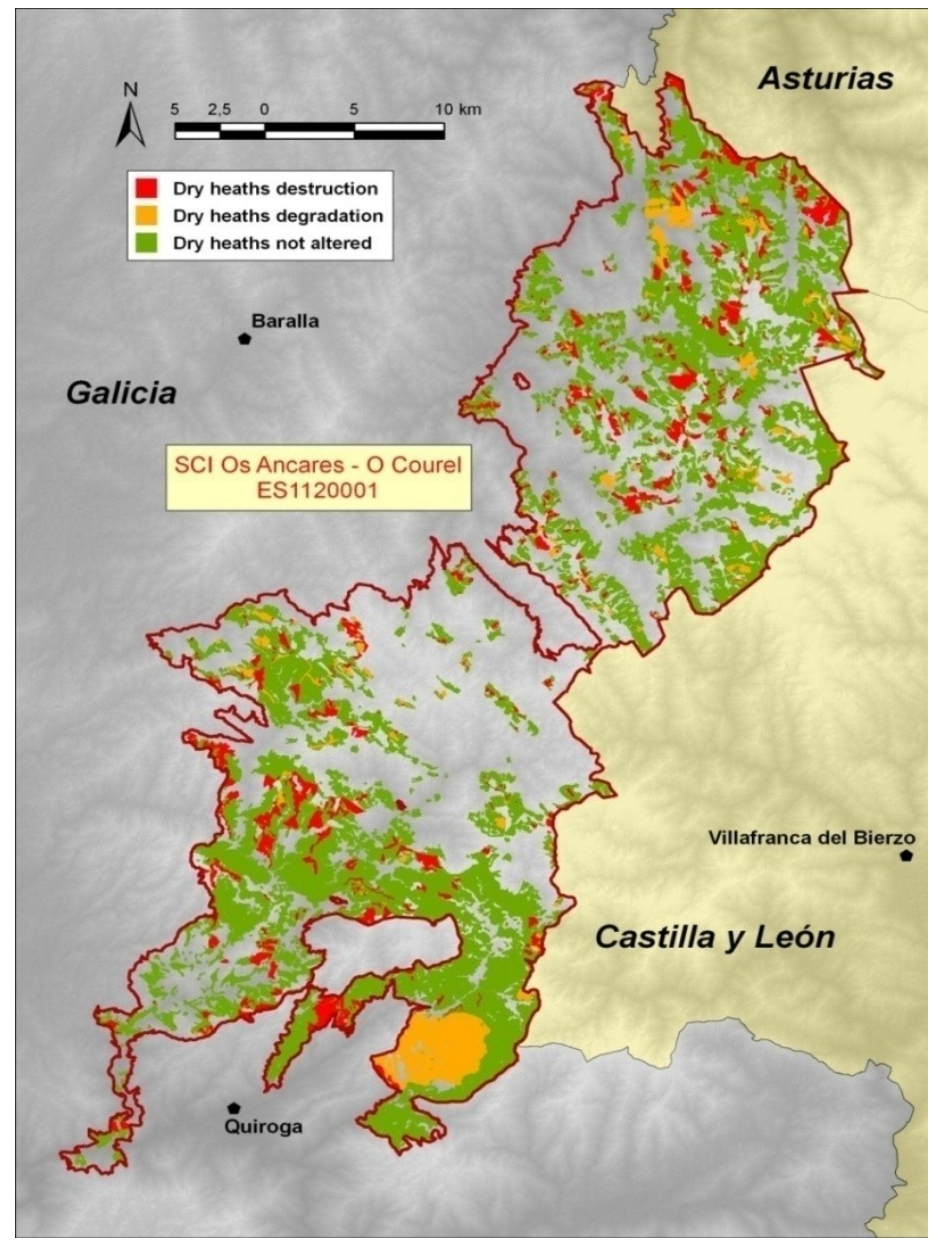

All the mapped units have summed an area of 7,066.3 ha, i.e., 20.3\% of the area originally occupied (2003) by European dry heaths (Table 1). The average size of the changing area is 5.9 ha. Minimum size units have registered less than $1,000 \mathrm{~m}^{2}(0.1 \mathrm{ha})$, while maximum size is 811.9 ha. There are no change areas due to recovery or increasing area of heathlands, neither replacement by other habitats (e.g., forests) due to natural succession processes.

Table 1. Total surfaces of the European dry heaths in the SCI Os Ancares-O Courel that were destroyed and degraded during the period 2003-2011.

\begin{tabular}{ccccccc}
\hline Changes & Tiles & Area (ha) & $\begin{array}{c}\text { Habitat } \\
\text { Percentage }\end{array}$ & $\begin{array}{c}\text { Mean } \\
\text { (ha) }\end{array}$ & $\begin{array}{c}\text { Minimum } \\
\text { (ha) }\end{array}$ & $\begin{array}{c}\text { Maximum } \\
\text { (ha) }\end{array}$ \\
\hline Dry heaths destruction & 840 & $4,018.4$ & $11.5 \%$ & 4.8 & $<0.1$ & 135.8 \\
Dry heaths degradation & 363 & $3,047.9$ & $8.8 \%$ & 8.4 & $<0.1$ & 811.9 \\
TOTAL & 1,203 & $7,066.3$ & $20.3 \%$ & 5.9 & $<0.1$ & 811.9 \\
\hline
\end{tabular}


The European dry heaths (Nat-2000 4030) total surface destroyed in the study area during the period 2003-2011 was 4,018.3 ha (Table 1), from a set of 840 map units. This means that the area occupied by dry heaths has been reduced in $11.6 \%$ along the period analyzed. Size units defined in this category range from less than 0.1 ha to 135.8 ha.

The dry heath surfaces that have undergone a significant degradation of their structural attributes during the studied period were as much as 3,047.9 ha (Table 1), distributed in a total of 363 tiles mapped. This represents an effect on the structure, composition and function in $8.8 \%$ of dry heath previously identified. Minimum size of degradation is less than $1,000 \mathrm{~m}^{2}$, while maximum size is 811.9 ha. However, the highest value is due to the occurrence of a single wildfire in 2006 , which has affected several heath units of more than 400 ha each. With the exception of this case, the highest value is $121 \mathrm{ha}$.

\subsection{Dry Heaths Destruction (2003-2011)}

The destruction of dry heaths has been registered in the SCI Os Ancares-O Courel between 2003-2011 because of the intensification of land uses or the establishing of different types of buildings and infrastructures. However, as detailed below, the degree of impact of these different types of changes on the habitat was unequal.

\subsubsection{Afforestations}

Afforestation with exotic species (Pinus pinaster, P. radiata, P. sylvestris, Eucalyptus spp., and Quercus rubra, Castanea $\times$ coudercii) was the main cause of destruction of dry heaths in the SCI Os Ancares-O Courel during the period 2003-2011. It represents $88 \%$ of the habitat surface destructed. Decrease of dry heaths due to afforestation occupies 3,534.9 ha, in 425 patches, assuming a loss of $10.2 \%$ of this habitat of community interest at the beginning of this period (Table 2). Minimum tile size is 0.1 ha, while maximum size was 135.8 ha. The fate of these stockings is timber production for different purposes (boarding, cellulose pulp, sawmilling, and veneer).

Table 2. Stats of causes of dry heaths destruction in the SCI Os Ancares-O Courel during the period 2003-2011.

\begin{tabular}{cccccccc}
\hline & Tiles & $\begin{array}{c}\text { Area } \\
\text { (ha) }\end{array}$ & $\begin{array}{c}\text { Habitat } \\
\text { Percentage }\end{array}$ & $\begin{array}{c}\text { Destruction } \\
\text { Percentage }\end{array}$ & $\begin{array}{c}\text { Mean } \\
\text { (ha) }\end{array}$ & $\begin{array}{c}\text { Minimum } \\
\text { (ha) }\end{array}$ & $\begin{array}{c}\text { Maximum } \\
\text { (ha) }\end{array}$ \\
\hline Afforestations & 425 & $3,534.9$ & $10.2 \%$ & $88.0 \%$ & 8.3 & 0.1 & 135.8 \\
Pasturelands & 357 & 435.7 & $1.2 \%$ & $10.8 \%$ & 1.2 & $<0.1$ & 18.3 \\
Infrastructures & 56 & 38.4 & $0.1 \%$ & $1.0 \%$ & $<0.1$ & $<0.1$ & 5.4 \\
Buildings & 1 & 0.1 & $<0.1 \%$ & $<0.1 \%$ & 0.1 & 0.1 & 0.1 \\
Quarries & 1 & 9.3 & $<0.1 \%$ & $0.2 \%$ & 9.3 & 9.3 & 9.3 \\
TOTAL & 840 & $4,018.4$ & $11.5 \%$ & $100.0 \%$ & 4.8 ha & $<0.1$ & 135.8 \\
\hline
\end{tabular}

\subsubsection{Pasturelands}

Another cause of substantial destruction of dry heaths is their transformation into pasturelands for feeding of cattle. This habitat loss has led to the disappearance of 435.7 ha (Table 2), $1.2 \%$ of the area 
initially occupied by dry heaths, and $10.8 \%$ of the total decrease registered in the period 2003-2011. We have mapped in this category 357 patches, with an average area of 1.2 ha. Largest surface affected by this cause was 18.3 ha, and the minimum size was less than 0.1 ha.

\subsubsection{Other Causes of Destruction}

Other causes of destruction of dry heaths in the SCI Os Ancares-O Courel during the period 2003-2011 have involved surfaces significantly lower than the previous cases (Table 2). Construction of infrastructures has led to the disappearance of 38.4 ha of dry heaths, while new buildings represented a decrease of 0.1 ha. Slate quarries have destroyed a total of 9.3 ha of dry heaths present in this SCI.

\subsection{Dry Heaths Degradation (2003-2011)}

The total dry heathland surface degraded in the SCI Os Ancares-O Courel between 2003-2011 has been 3,047.9 ha (Table 3). This supposes a strong impact on its structure, composition and function affecting up to $7.4 \%$ of the original surface for this habitat.

Table 3. Stats of the different causes for the degradation of dry heaths in the SCI Os Ancares-O Courel during the period 2003-2011.

\begin{tabular}{cccccccc}
\hline & Tiles & $\begin{array}{c}\text { Area } \\
\text { (ha) }\end{array}$ & $\begin{array}{c}\text { Habitat } \\
\text { Percentage }\end{array}$ & $\begin{array}{c}\text { Degradation } \\
\text { Percentage }\end{array}$ & $\begin{array}{c}\text { Mean } \\
\text { (ha) }\end{array}$ & $\begin{array}{c}\text { Minimum } \\
\text { (ha) }\end{array}$ & $\begin{array}{c}\text { Maximum } \\
\text { (ha) }\end{array}$ \\
\hline Wildfires & 35 & $2,286.2$ & $6.6 \%$ & $75.0 \%$ & 65.3 & 0.2 & 811.9 \\
Brushing outs & 328 & 761.7 & $2.2 \%$ & $25.0 \%$ & 2.3 & $<0.1$ & 29.3 \\
& 363 & $3,047.9$ & $8.8 \%$ & $100.0 \%$ & 8.4 & $<0.1$ & 811.9 \\
\hline
\end{tabular}

\subsubsection{Wildfires}

Wildfires have been the main cause degrading the structure and function of the dry heaths in the SCI Os Ancares-O Courel during the period 2003-2011, because of they represent $75 \%$ of degraded area. Fires have affected 2,286.2 ha, as much as 6.6\% of dry heathland present in the SCI in 2003 (Table 3). We have mapped 35 tiles within this cause, with an average size of 65.3 ha. This average value is high, because of the occurrence of an extensive wildfire in 2006, which devastated more than 1,500 ha of dry heath in the southeastern part of the SCI. These were spread over several large areas, more than 400 ha each, with a maximum of 811.9 ha. Remaining areas of dry heathland degradation due to wildfires are among 0.2 ha and 121 ha.

\subsubsection{Brushing Outs}

These are made for different purposes in the SCI Os Ancares-O Courel, and are other causes of degradation of the structure and functionality of dry heaths. These brushing outs have affected 761.7 ha, $1.9 \%$ of the original dry heaths surface (Table 3). The number of units mapped by this cause was 328 , representing $90 \%$ of tiles of heathland degraded, although their total surface only represents $25 \%$ 
of the area degraded between 2003-2011. Maximum size defined for this cause has been 29.3 ha, while the minimum was less than $1,000 \mathrm{~m}^{2}$.

\subsection{Dry Heaths Fragmentation (2003-2011)}

In order to assess the impact of the changes detected on the degree of fragmentation of the European dry heaths, we have calculated the most widely used indicators [51]. Fragmentation indicators are calculated on the sets of patches occupied by dry heaths in the years 2003 and 2011. Results are showed in Table 4.

Table 4. Comparison of fragmentation indicators of European dry heaths mapped in the SCI Os Ancares-O Courel during the period 2003-2011.

\begin{tabular}{cccccc}
\hline & Patches & Average size (ha) & Maximum size (ha) & Edge (km) & ANN \\
\hline 2003 & 1,543 & 25.7 & $2,690.2$ & $5,948.1$ & 1.43 \\
2011 & 1,730 & 18.8 & $1,840.6$ & $6,210.0$ & 1.58 \\
\hline
\end{tabular}

Number of dry heaths patches has increased from 1,543 to 1,730 due to breakage caused by heath losses. Mean patch size in 2003 is 25.7 ha, falling to 18.8 ha in the year 2011. Maximum size was $2,690.2$ ha in 2003 , dropping to $1,840.6$ ha in 2011. Moreover, the total sum of the patches edge has increased from $5,948.1 \mathrm{~km}$ to $6,210.0 \mathrm{~km}$. Value of average nearest neighbor (ANN) ratio [52] has also increased between 2003 and 2011, from 1.43 to 1.58. All computed values are indicative of an increasing degree of fragmentation of the European dry heaths existing in the SCI Os Ancares-O Courel (Table 4) as a result of the heath destruction and degradation caused between 2003-2011.

\subsection{Future Projection (until 2025)}

We have determined the average annual rates of destruction and degradation of dry heaths during the analyzed period (2003-2011). This information let us calculate a future projection (2025 year) of heath loss in the SCI Os Ancares-O Courel, whereas these rates remain constant (Table 5).

Table 5. Future projections to 2025 of European dry heaths loss in the SCI Os Ancares-O Courel.

\begin{tabular}{ccccc}
\hline & $\begin{array}{c}\text { Area } \\
\text { 2003-2011(ha) }\end{array}$ & $\begin{array}{c}\text { Annual } \\
\text { average (ha) }\end{array}$ & $\begin{array}{c}\text { Projection } \\
\mathbf{2 0 0 3 - 2 0 2 5} \text { (ha) }\end{array}$ & $\begin{array}{c}\text { Lost Habitat } \\
\mathbf{2 0 0 3}-\mathbf{2 0 2 5}(\mathbf{2})\end{array}$ \\
\hline Dry heaths destruction & $4,018.4$ & 502.3 & $11,050.7$ & 31.8 \\
Dry heaths degradation & $3,047.9$ & 338.7 & $8,381.7$ & 24.1 \\
DRY HEATHS LOSS & $7,066.3$ & 785.1 & $19,432.4$ & 55.9 \\
\hline
\end{tabular}

Computed projections show that destruction of dry heaths would reach in $202511,050.7$ ha, i.e., $31.8 \%$ of heaths present in space in 2003, while the degraded areas would sum 8,381.7 ha, 24.1\%. Together, they would reach 19,432.4 hectares of dry heathland loss. Thus, during the period 2003-2025 more than a half (55.9\%) of the area initially occupied by heaths would have been subjected to actions in conflict with the objectives of the Council Directive 92/43/EEC and the Natura 2000 network (Figure 7) for maintaining or restoring them at favorable conservation status. 
Figure 7. Rates of destruction and degradation of dry heaths in the SCI Os Ancares-O Courel. (a) 2003-2011 period; (b) 2003-2025 projection.

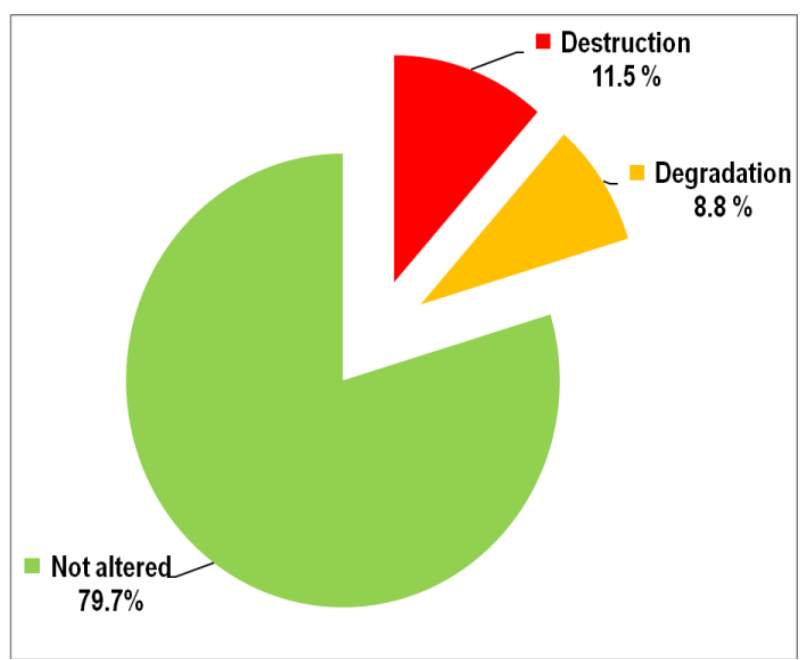

(a)

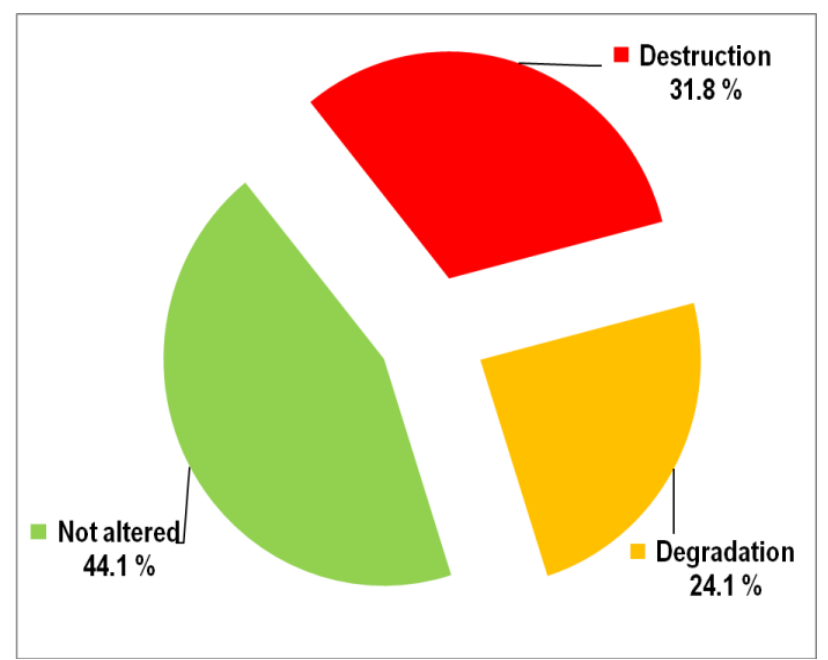

(b)

\section{Discussion}

\subsection{Methodological Issues}

Geographic Information Systems (GIS) become an essential tool in assessing natural resources and biodiversity [53,54]. The use of GIS in our study has enabled the definition of change areas between the years 2003 and 2011 for the European dry heaths (Nat-2000 4030) existing in the SCI Os Ancares-O Courel. The availability of high resolution imagery $(0.25 \mathrm{~cm}$ pixel size $)$ has positively supported the accuracy achieved in the definition and determination of the causes of change, allowing the assessment of the first two criteria that according to Council Directive 92/43/EEC define the favorable conservation status of that habitat of community interest.

The methodology has proven to be very valuable for surveillance and regular evaluation of conservation status of dry heaths. This is especially important in an extensive rugged territory as the SCI Os Ancares-O Courel. This process is also applicable to other large areas of difficult access that were occupied by other habitat types whereby identification was possible due to their large spatial representation (scrublands, forests, wetlands, dunes, etc.). In these cases, the use of photo-interpretation techniques allows the quantifying of the processes of change of habitat as we have done in this paper.

However, the results of assessments made with this methodology in our study might be mandatorily supplemented with other direct and specific studies to be able to evaluate the third of the criteria for favorable conservation status of a habitat ("assessment conservation status of typical species of habitat").

Moreover, and in order to improve the techniques for assessment and monitoring of the conservation status of habitats in the Natura 2000 areas, it is necessary to extend this kind of study to other geographic areas (SCIs, SACs and SPAs) and to compare them with results obtained here. Furthermore, the results obtained by applying these methods may help to establish the management guidelines for the protection of the natural heritage in the Natura 2000 network where, in each case, 
the biodiversity conservation may be combined with the regional and local characteristics of the site and also with their own economic, social and cultural requirements.

\subsection{Dry Heaths Destruction}

Massive afforestation occurring since the late 19th century and conducted or encouraged by public bodies has been one of the major causes driving towards the loss of heathland superficies in Galicia. Previously, heathlands were a relevant part of agroforestry system because of they were a source of fertilizer, fuel and fodder for domestic livestock [35]. Since the middle of the 20th century extensive monospecific Pinus (P. pinaster, P. radiata, P. sylvestris) and Eucalyptus globulus plantations were established in this region which transformed and destroyed wide surfaces of heathland [55]. This process has also affected the territory included within the SCI Os Ancares-O Courel, where nearly 7,000 ha of afforestations [45] were conducted or promoted by the Forest Administration.

The Common Agricultural Policy (CAP) framework has not served to change this habitat destruction trend. Instead of this, the European Community funds have continued financing afforestations developed at the expense of natural habitats [56,57], first under the goal of afforestation of agricultural land (CAP reform 1992) and, more recently, under the umbrella of the agri-environmental policies (1999 and subsequent amendments). According to the results of this study, afforestations have been the main cause of destruction of dry heaths in the SCI Os Ancares-O Courel in the period 2003-2011, promoting the destruction of more than 3,500 ha of European dry heaths (Nat-2000 4030), 10.2\% of its original surface.

Second cause of dry heath destruction was its transformation to pasturelands. This has meant a decrease of 435.7 ha, $1.2 \%$ of the area originally occupied by this habitat type of community interest. Transformation of dry heathland to pasturelands is developed in order to increase livestock production [58]. Substitution of traditional grazing methods on dry heaths [27] by intensive pasturelands sowed with genetically improved varieties also resulted in a problem for natural conservation, because of the introduction of non-native genotypes in sensitive natural areas. This phenomenon is not only a threat to heathland surfaces [28,59], but also causes disruption to their species composition [60,61]. Dry heaths transformed to pasturelands have also been financed or co-financed by the European agri-environmental policies.

Several authors have questioned the effectiveness of agri-environment schemes in the maintenance and restoration of biodiversity [62,63]. In accordance with these, in Galicia they have been far from being used as a tool to promote sustainable farming and biodiversity conservation. Instead, agri-environment schemes have been used to support farm incomes regardless of the environmental consequences of the funded activities [64]. This has been evident in the SCI Os Ancares-O Courel during the period 2003-2011, where 11.4\% (almost 4,000 ha) of the area occupied by the European dry heaths (Nat-2000 4030), a habitat of community interest, has been destroyed because of actions (afforestations and pasturelands) supported by agri-environment funds.

Transformation of heaths due to replacement of traditional management for new intensive land uses has been described thoroughly [65]. Some authors have linked historical heathland loss with increasing rural population, and therefore with the increase of cultivated area [35]. However, the area included in the SCI Os Ancares-O Courel presents a continuous population regression since the early 20th century [66]; 
and during the period 2003-2011, such regression was simultaneous to the dry heaths destruction. In this case, the CAP has led to a dramatic shift in the uses of dry heaths in the SCI Os Ancares-O Courel: instead of promoting environmentally sustainable farming in a context of population decline and rural exodus, agri-environment schemes have produced damage to biodiversity by intensification land uses and transforming natural habitats.

\subsection{Dry Heaths Degradation}

For thousands of years fire has been traditionally used in the mountain areas of NW Iberia and in other parts of Europe as a tool for regeneration of pasture [35,67,68]. Its use was limited in time and space, so fires rarely affected large areas. Actually, this traditional practice is no longer practiced. The sharp decline in population experienced during the 20th century and the small proportion of that population that performed farming tasks led to an increase in the extension of dry heaths and other shrubs. Large scrubland formations are perceived by local people and public managers as unproductive areas. They are also considered a refuge for species (roe deer, wild boar, wolf) that can cause losses to crops and livestock. Although the current legislative framework prohibits the arbitrary use of fire, this is still applied, very often, to exercise indirect control over these animal species, and also in renewing large grazing areas with low costs.

Some studies have shown that the correct selection of the most suitable time to do it, using low intensity and small size prescribed burning, may maintain certain levels of biodiversity in heathlands [69,70]. However, there are no reliable data about prescribed burning effects on biodiversity in the study area. Nevertheless, uncontrolled wildfires often affect large areas, with high recurrence rate, reaching very severe intensities because they often occur in summer, when the soil moisture is low. This fact has been recorded during the period 2003-2011 in the SCI Os Ancares-O Courel, when wildfires affected $2,286.2$ ha, $6.6 \%$ of dry heathland in 2003 .

Several authors have shown that severe wildfires often involve serious effects on dry heaths biodiversity [28,71]. This kind of fire affects large areas with tall and very dense dry heaths, reaching temperatures of more than $400{ }^{\circ} \mathrm{C}$ as recorded at soil surface in bushfires in NW Spain [72]. Therefore, non-controlled wildfires not only destroy the aerial part of the plant, but also carry the combustion of the first centimeters of soil, destroying the organic matter and burning the roots, buds and seeds, equally affecting all the existing wildlife populations and $\mathrm{C}$ stocks [73-75], followed by erosion processes provided by the steep slopes in the study area. Consequently, heath revegetation is eventually inhibited due to the occurrence of severe fires [76-78].

Brushing outs developed in the SCI Os Ancares - O Courel during the period 2003-2011 have affected $1.9 \%$ of the area occupied by the dry heaths in 2003. In some cases these brushing outs have reached close to 30 ha in a single action made for different purposes. Sometimes these surfaces are sown with cereals (rye) for the creation of biotopes that support and feed partridge (Alectoris rufa) populations, which are reintroduced for hunting. In other cases, brushing outs were made in order to facilitate the establishment of bilberry communities (Vaccinium myrtillus) which serve as food for brown bear (Ursus arctos) populations. However, there is no scientific study linking benefits on plantigrade populations and increasing proportion of blueberry bushes. In other cases, fate of the 
brushing outs is unclear. At any rate, these actions should have a scientific backing in view of the fact that they affect the structure and function of European dry heaths (Nat-2000 4030).

\subsection{Dry Heaths Loss}

Both the destruction and degradation of natural habitats contribute to the habitat loss phenomenon [50]. Results obtained in this work show a loss of $20.3 \%$ of the European dry heaths in SCI Os Ancares-O Courel during the period 2003-2011 (Table 1). This SCI designation was made by taking into account habitat types of community interest hosts, highlighting the dry heaths that occupied more than 34,700 ha (33.9\% of SCI). Consequently, dry heathland management should aim to maintain or restore at favorable conservation status. Far from achieving these goals, a deterioration in the conservation status of the European dry heaths (Nat-2000 4030) following the SCI Os Ancares-O Courel adoption in 2004 has occurred. Therefore, it is evident that this type of SCI management does not contribute to attainment of the objectives of the Council Directive 92/43/EEC and of the Natura 2000 network.

Figure 8. Change areas occupied by scrubs in Galicia according to Spanish Forest Inventories (IFN).

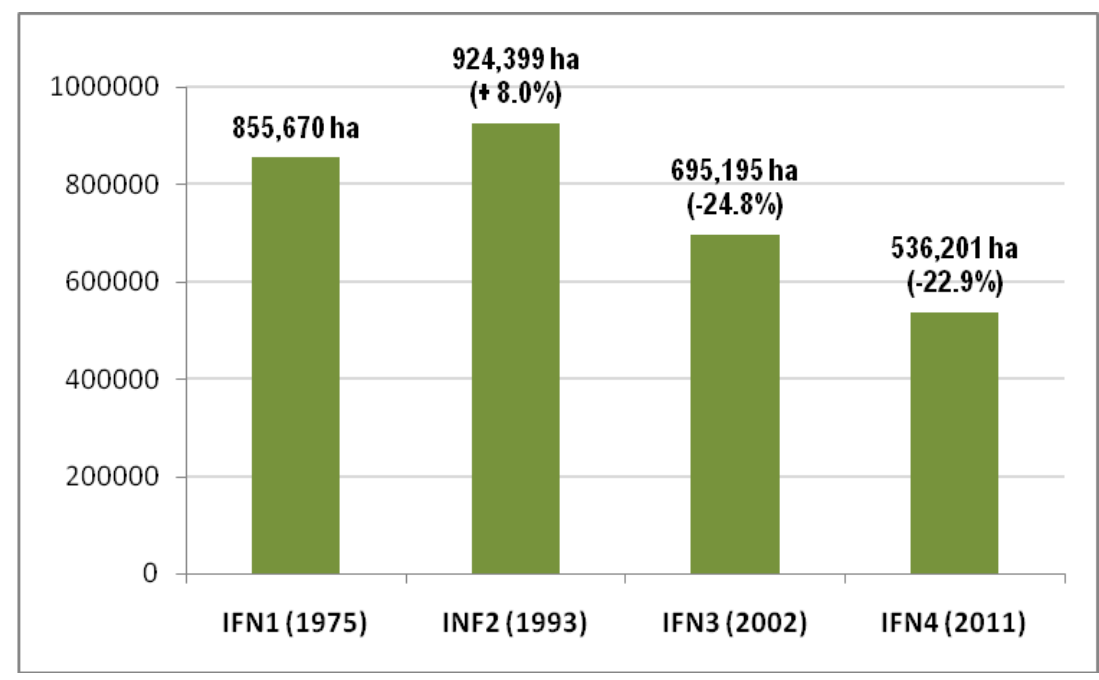

Heathland loss across Europe has led to consider it as a habitat type of community interest, and hence the need to designate special conservation areas (Natura 2000). Available information about the loss rate for the Galician heaths is very scarce and sourcing from different methodologies [79-88]. According to information provided by Spanish Forest Inventories (IFN), bushes declined in Galicia over $20 \%$ per decade during the past 20 years (Figure 8 ). Results obtained in this paper indicate that loss rate for heathland in the SCI Os Ancares-O Courel during the period 2003-2011 follows a slightly lower but similarly decreasing pattern.

\subsection{Fragmentation and Connectivity}

Loss of natural habitats is a global problem, which has been taken into account both in the Strategic Plan for Biodiversity 2011-2020 as in the European Biodiversity Strategy to 2020 [39]. It is also the main factor in adopting the current European habitat conservation framework represented by the Council Directive 92/43/EEC. Habitat loss often implies a process of fragmentation of remaining areas 
that can be a threat as great as the habitat loss, especially for certain animal species that require large surface vital areas $[89,90]$.

Most of the European natural habitats are subject to a high degree of fragmentation, as a result of the historic human occupation and the generalization of intensive and extensive methods of production adopted since the Industrial Revolution [56]. The European dry heaths in particular have suffered the effects of intensification trends, both at global and regional scale. However, there are few detailed studies about replacement of natural and semi-natural habitats and their effects over the degree of fragmentation [91].

The European dry heaths loss mapped in the SCI Os Ancares-O Courel along the period 2003-2011 has revealed an increase in the degree of fragmentation of this habitat, which is evidenced by the increasing number of patches, the reduction of the patch size, and the increasing distance between patches. All these effects are indicative signs that the fragmentation is increasing [51] but the connectivity reduced [92]. In this sense, the Council Directive 92/43/EEC establishes the need to promote and integrate habitat connectivity in environmental and spatial planning policies, in order to improve the ecological coherence of the Natura 2000 network. In this connection, we have computed that the dry heaths management developed during the period 2003-2011 in the SCI Os Ancares-O Courel have produced the opposite effect to the goals pursued by the European nature conservation framework.

This trend in increasing fragmentation and loss of connectivity of heathland has been previously evidenced for other habitat types in the SCI Os Ancares-O Courel and it caused negative effects over biodiversity, e.g., the extinction of an emblematic protected species, the capercaillie (Tetrao urogallus) that occurred in the last 30 years [93].

\subsection{Trends and Future Challenges}

The decreasing trend of conservation status of dry heaths detected in the SCI Os Ancares-O Courel during the period 2003-2011 contrasts with management strategies developed for this habitat type in other European areas (France, United Kingdom, Holland, Belgium), both in areas included in the Natura 2000 network and beyond [94-100]. To halt heathland loss, these plans set as primary targets the maintenance and increasing of areas occupied by heaths, maintenance and improvement of their conservation status, reducing fragmentation, implementation of restoration measures and removal of threats. Usually, the actions planned try to recover or emulate traditional management, whereby impact on the composition, structure and function of heathland is properly documented in each case $[29,66,67,101-106]$. These measures are complemented by public awareness programs for broadcasting and sharing with society key issues of heathlands, such as ethnographic and cultural values or ecosystem services, highlighting positive aspects of their conservation.

These strategies follow a proactive trend, trying to keep the heathland in a favorable conservation status. From an economic standpoint, proactive policies are appropriate for the biodiversity conservation, in view that the cost-saving recovery/restore minimizes the risk of irreversible environmental damages [107]. In contrast, reactive interventions that are mandatory only when the risk of biodiversity loss is high, or when the environmental authorities decide it may be too expensive, or may arrive too late, when it is no longer possible to be recovered the lost resource. 
This is the first regional work on detailed monitoring and surveillance of the conservation status of a habitat type according to the criteria of the Council Directive 92/43/EEC. While there is no standardized methodology or regional monitoring plan, the use of remote sensing and high resolution images are revealed as the quickest and cheapest method in view of the accuracy achieved, consistent with the provisions of other authors in different areas or scales $[43,44,46,47,53,54]$. Therefore, it should be necessary that results obtained in this paper be contrasted with similar analyses in other SCIs/SACs, to check if trends computed in the SCI Os Ancares-O Courel are part of a regional or global dry heaths management model, or instead is an isolated case.

\section{Conclusions}

We have computed that the conservation status of European dry heaths habitat (Nat-2000 4030) has decreased in SCI Os Ancares-O Courel (Galicia, NW Spain) between 2003 and 2011. The use of high-resolution aerial imagery analysis and Geographic Information Systems (GIS) was revealed as especially appropriate for the assessment and surveillance of habitat types of community interest covering large rugged areas where the access is very difficult. The ease of identification of habitats types impacted positively on the applicability of the method followed.

More than 7,000 hectares (20.3\% of habitat type) of European dry heaths were lost by human activities during the studied period. The loss rate calculated indicates that, by 2025, a European dry heaths loss of more than a half (55.9\%) in SCI Os Ancares-O Courel can be expected. European dry heaths loss recorded is due to replacement of traditional management for new intensive land uses. Not only dry heaths loss has been produced between 2003 and 2011, but also the degree of fragmentation has increased.

The main causes (afforestations, pasturelands) of heathland loss and fragmentation have been financed through EU funds from agri-environmental schemes, lacking the necessary scientific backing. Rather than promote and protect the biodiversity, these activities have facilitated the loss of a habitat type of community interest, causing negative effects over biodiversity.

All the recorded results show heathland management contrary to a Natura 2000 area declaration, following a trend that does not achieve the objectives stated in the Council Directive 92/43/EEC for Natura 2000. This situation contrasts with other areas of the European Union, where proactive measures for conservation have been put in place under scientific criteria, both within the Natura 2000 network, and outside of it.

\section{Conflicts of Interest}

The authors declare no conflict of interest.

\section{References}

1. Díaz González, T.E. Síntesis de la vegetación arbustiva de Europa occidental. I: Brezales (Calluno-Ulicetea) (In Spanish). Itinera geobotanica 1998, 11, 7-31.

2. Loidi, J.; Biurrun, I.; Campos, J.A.; García-Mijangos, I.; Herrera, M. A survey of heath vegetation of the Iberian Peninsula and Northern Morocco: A biogeographical and bioclimatic approach. Phytocoenologia 2007, 37, 341-370. 
3. Loidi, J.; Biurrun, I.; Campos, J.A.; García-Mijangos, I.; Herrera, M. A biogeographical analysis of the European Atlantic lowland heaths. J. Veg. Sci. 2010, 21, 832-842.

4. Ojeda, F. 4030 Brezales Secos Europeos. In Bases Ecológicas Preliminares Para la conservación de los Tipos de Hábitat de Interés Comunitario en España (In Spanish); Ministerio de Medio Ambiente, y Medio Rural y Marino: Madrid, Spain, 2008; p. 66.

5. Simes, N.; Day, J. A Practical Guide to the Restoration and Management of Lowland Heathland; The Royal Society for the Protection of Birds: Bedforshire, UK, 2003.

6. Simonson, W.; Thomas, R. Biodiversity: Making the Links; English Nature: Peterborough, UK, 1999.

7. Parry, J. Heathland; National Trust: London, UK, 2003.

8. Alonso, I. La conservación de los brezales en Inglaterra (In Spanish). Ecosistemas 2004, 13, 111-118.

9. Tischendorf, L.; Fahrig, L. On the usage and measurement of landscape connectivity. Oikos 2000, 90, 7-19.

10. Taylor, P.D.; Fahrig, L.; Heinken, K.; Merriam, G. Connectivity is a vital element of landscape structure. Oikos 1993, 68, 571-572.

11. Graebner, P. Die Heide Nordwestdeutschlands. In Die Vegetation der Erde (In German); Engler, A., Drude, O., Eds.; Wilhelm Engelmann: Leipzig, Germany, 1901; pp. 320.

12. Watt, A.S. Pattern and process in the plant community. J. Ecol. 1947, 35, 1-22.

13. Tüxen, R. Über die räumliche, durch Relief und Gestein bedingte Ordnung der natürlichen Waldgesellschaften am nördlichen Rande des Harzes (In German). Vegetatio 1954, 5-6, 454-478.

14. Braun-Blanquet, J.; Tüxen, R. Irische Pflanzengesellschaften (In German). Veröff. Geobot. Inst. 1952, 25, 222-421.

15. Rothmaler, W. Vegetationsstudien in Nordwestspanien. Vegetatio 1954, 5-6, 595-601.

16. Ellenberg, H. Vegetation Mitteleuropas mit den Alpen (In German); Ulmer: Stuttgart, Germany, 1963.

17. Bellot, F. La vegetación de Galicia (In Spanish). An. Inst. Bot. Cavanilles 1968, 24, 3-306.

18. Barclay-Estrup, P.; Gimingham, C.H. The description and interpretation of cyclical processes in a heath community: I. vegetational change in relation to the calluna cycle. J. Ecol. 1969, 57, 737-758.

19. Gimingham, C.H. Ecology of Heathlands; Chapman \& Hall: London, UK, 1972.

20. Géhu, J.; Géhu, J.-M. Contribution à l'étude phytosociologique des landes du sud-ouest de la France (In French). Colloq. Phytosiol. 1975, 2, 75-89.

21. Rivas-Martínez, S. Brezales y jarales de Europa occidental (Revisión fitosociológica de las clases Calluno-Ulicetea y Cisto-Lavanduletea) (In Spanish). Lazaroa 1979, 1, 5-127.

22. Damman, A.W.H. The south-Swedish Calluna-heath and its relation to the Calluneto-Genistetum. Bot. Notiser 1957, 110, 363-398.

23. Moore, N.W. The heaths of dorset and their conservation. J. Ecol. 1962, 50, 369-391.

24. De Schmidt, J.T. Origin and Destruction of Northwest European Heath Vegetation. In Werden und Vergehen von Pflanzengesellschaften (In German); Wilmanns, O., Tüxen, R., Eds.; Cramer: Vaduz, Liechtenstein, 1979; pp. 411-435.

25. Specht, R.L. Heathlands and Related Shrublands of the World. In Heathlands and Related Shrublands; Specht, R.L., Ed.; Elsevier: Amsterdam, Holland, 1979; pp. 1-18.

26. Webb, N.R.; Haskins, L.E. An ecological survey of heathlands in the Poole basin, Dorset, England in 1978. Biol. Conserv. 1980, 17, 281-296. 
27. Webb, N.R. Changes in heathlands of Dorset, England, between 1978 and 1987. Biol. Conserv. 1990, 51, 273-286.

28. Farrell, L. Lowland Heath: Extent of Habitat Change; English Nature: Peterborough, UK, 1993.

29. Gimingham, C.H. Lowland heaths of West Europe: Management for conservation. Phytocoenologia 1994, 24, 615-626.

30. Blackstock, T.H.; Stevens, J.P.; Howe, E.A.; Stevens, D.P. Changes in the extent and fragmentation of heathland and other semi-natural habitats between 1920-1922 and 1987-1988 in the Llyn Peninsula, Wales, UK. Biol. Conserv. 1995, 72, 33-44.

31. Noirfalise, A.; Vanesse, R. Les Landes à bruyère de I'Europe Occidentale (In French); Council of Europe: Strasbourg, France, 1976.

32. Ramil-Rego, P.; Muñoz-Sobrino, C.; Rodríguez-Guitián, M.A.; Gómez-Orellana, L. Differences in the vegetation of the North Iberian Peninsula during the last 16,000 years. Plant Ecol. 1998, $138,41-62$.

33. Muñoz Sobrino, C.; Ramil Rego, P.; Rodríguez Guitián, M.A. Upland vegetation in the north-west Iberian peninsula after the last glaciation: Forest history and deforestation dynamics. Veg. Hist. Archaeobot. 1997, 6, 215-233.

34. Gómez-Orellana, L.; Ramil-Rego, P.; Muñoz Sobrino, C. The Würm in NW Iberia, a pollen record from Area Longa (Galicia). Quaternary Res. 2007, 67, 438-452.

35. Izco, J.; Amigo, J.; Ramil-Rego, P.; Díaz, R.; Sánchez, J.M. Brezales: Biodiversidad, usos y conservación (In Spanish). Recursos Rurais 2006, 2, 5-24.

36. Soulé, M.E. Conservation Biology: The Science of Scarcity and Diversity; Sinauer: Sunderland, MA, USA, 1986.

37. Groombridge, B. Global Biodiversity: State of the Earth's Living Resources; Chapman and Hall: New York, NY, USA, 1992.

38. Forman, T.T. Land Mosaics: The Ecology of Landscapes and Regions; Cambridge University Press: New York, NY, USA, 1996.

39. European Commission. Our Life Insurance, Our Natural Capital: An EU Biodiversity Strategy to 2020; European Commission: Brussels, Belgium, 2011.

40. Os Hábitats de Interese Comunitario en Galicia. Descrición e Valoración Territorial (In Galician). Available online: http://www.ibader.org/archivos/docs/habitats_interese_comunitario_galicia_ valoracion.pdf (accessed on 13 May 2013).

41. Os Hábitats de Interese Comunitario en Galicia. Fichas Descritivas (In Galician). Available online: http://www.ibader.org/archivos/docs/habitats_interese_comunitario_galicia_fichas.pdf (accessed on 13 May 2013).

42. Weiers, S.; Bock, M.; Wissen, M.; Rossner, G. Mapping and indicator approaches for the assessment of habitats at different scales using remote sensing and GIS methods. Landscape Urban Plan. 2004, 67, 43-65.

43. Díaz Varela, R.A.; Ramil Rego, P.; Calvo Iglesias, S.; Muñoz Sobrino, C. Automatic habitat classification methods based on satellite images: A practical assessment in the NW Iberia coastal mountains. Environ. Monit. Assess. 2008, 144, 229-250.

44. Martínez Sánchez, S.; Ramil Rego, P.; Hinojo Sánchez, B.; Chuvieco Salinero, E. Assessing Loss of Biodiversity in Europe Through Remote Sensing: The Necessity of New Methodologies. 
In Biodiversity Loss in a Changing Planet; Grillo, O., Venora, G., Eds.; Intechweb.org: Rijeka, Croatia, 2011; pp. 19-48.

45. Rigueiro Rodríguez, A.; Ramil Rego, P.; Crecente Maseda, R.; Rodríguez Guitián, M.A. Plan de Ordenación de los Recursos Naturales del Espacio Natural Protegido Os Ancares-O Courel; Dirección Xeral de Conservación da Natureza: Santiago de Compostela, Spain, 2005.

46. Haest, B.; Thoonen, G.; Vanden Borre, J.; Spanhove, T.; Delalieux, S.; Bertels, L.; Kooistra, L.; Mücher, C.A.; Scheunders, P. An Object-Based Approach to Quantity and Quality Assessment of Heathland Habitats in the Framework of Natura 2000 Using Hyperspectral Airborne AHS Images. In GEOBIA 2010-Geographic Object-Based Image Analysis; Addink, E.A., van Coillie, F.M.B., Eds.; Ghent University: Ghent, France, 2010.

47. Thoonen, G.; Spanhove, T.; Haest, B.; Vanden Borre, J.; Scheunders, P. Habitat Mapping and Quality Assessment of Heathlands Using A Modified Kernel-Based Reclassification Technique. In Proceedings of the 2010 IEEE International Geoscience and Remote Sensing Symposium (IGARSS), Honolulu, HI, USA, 25-30 July 2010; pp. 2707-2710.

48. Ramil Rego, P.; Rodríguez Guitián, M.A.; Rubinos Román, M.; Ferreiro da Costa, J.; Hinojo Sánchez, B.; Blanco López, J.M.; Sinde Vázquez, M.; Gómez-Orellana Rodríguez, I.; Díaz Varela, R.; Martínez Sánchez, S. La expresión territorial de la biodiversidad. Paisajes y hábitats. Recursos Rurais 2005, 2, 109-128.

49. Stein, B.A.; Kutner, L.S.; Adams, J.S. Precious Heritage: The Status of Biodiversity in the United States; Oxford University Press: New York, NY, USA, 2000.

50. ESRI. ArcGIS Desktop 10.1; Environmental Systems Research Institute, Inc: Redlands, CA, USA, 2012.

51. Fahrig, L. Effects of habitat fragmentation on biodiversity. Annu. Rev. Ecol. Evol. S. 2003, 34, 487-515.

52. Ebdon, D. Statistics in Geography; Blackwell Publishers: Oxford, UK, 1985.

53. Jones, P.G.; Beebe, S.E.; Tohme, J.; Galwey, N.W. The use of geographic information systems in biodiversity exploration and conservation. Biodivers. Conserv. 1997, 6, 947-958.

54. Guarino, L.; Jarvis, A.; Hijmans, R.J.; Maxted, N. Geographic Information Systems (GIS) and the Conservation and Use of Plant Genetic Resources. In Managing Plant Genetic Diversity; Engels, J.M.M., Ramanatha Rao, V., Brown, A.H.D., Jackson, M.T., Eds.; CABI Publishing: Oxford, UK, 2002; pp. 387-404.

55. Rico Boquete, E. Política forestal e repoboacións en Galicia (1941-1971) (In Galician); Servicio de Publicacións e Intercambio Científico da Universidade de Santiago de Compostela: Santiago de Compostela, Spain, 1995.

56. Prada, A. Montes e Industria. O Circuito da Madeira en Galicia (In Galician); Fundación Caixa Galicia: A Coruña, Spain, 1991.

57. Ramil Rego, P.; Muñoz Sobrino, C.; Gómez-Orellana, L.; Rodríguez Guitián, M.A.; Ferreiro da Costa, J. Configuración y transformacion del paisaje del NW ibérico durante el final de los tiempos glaciares, el Holoceno y el Antropoceno (In Spanish). Recur. Rurais Serie Cursos 2012, 6, 19-62.

58. Sineiro, F.; Osoro, K.; Díaz, N. Bases para la producción e intensificación ganadera en el monte gallego: La utilización de la vegetación espontánea y la siembra y mejora del pasto. In Pastos y 
Forrajes en Alimentación Animal. Actas de la XXII Reunión Científica de la Sociedad Ibérica de Nutrición Animal (In Spanish); SINA: Santiago de Compostela, Spain, 1984; pp. 195-219.

59. Webb, N.R. Heathlands; Collins: London, UK, 1986.

60. Rosa García, R.; García, U.; Osoro, K.; Celaya, R. Ground-dwelling arthropod assemblages of partially improved heathlands according to the species of grazer and grazing regime. Eur. J. Entomol. 2011, 108, 107-115.

61. Rose, R.J.; Webb, N.R.; Clarke, R.T.; Traynor, C.H. Changes on the heathlands in Dorset, England, between 1987 and 1996. Biol. Conserv. 2000, 93, 117-125.

62. Sheehy-Skeffington, M.; Bleasdale, A.; McKee, A. Research in the Connemara Uplands: Vegetation Changes and Peat Erosion. In Seeking a Partnership Towards Managing Ireland's Uplands; Hogan, D., Phillips, A., Eds.; Irish Uplands Forum: Galway, Ireland, 1996; pp. 143-148.

63. Kleijn, D.; Baquero, R.A.; Clough, Y.; Díaz, M.; de Esteban, J.; Fernández, F.; Gabriel, D.; Herzog, F.; Holzschuh, A.; Jöhl, R.; et al. Mixed biodiversity benefits of agri-environment schemes in five European countries. Ecol. Lett. 2006, 9, 243-254.

64. García Arias, A.I. A Política Agroambiental da Unión Europea en Galiza. Análise da súa Aplicación no Período 1997-2006. Ph.D. Thesis, Universidade de Santiago de Compostela, Lugo, Spain, 2008.

65. Plieninger, T.; Höchtl, F.; Spek, T. Traditional land-use and nature conservation in European landscapes. Environ. Sci. Policy 2006, 9, 317-321.

66. Fernández Fernández, M. A Poboación na Provincial de Lugo: Evolución Recente e Perspectivas de Futuro. In Plan Estratéxico da Provincia de Lugo (In Spanish); Meixide Vecino, A., Fernández Fernández, M., Marey Pérez, M.F., Eds; Deputación de Lugo: Lugo, Spain, 2010; pp. 32-67.

67. Gimingham, C.H. The Lowland Heathland Management Handbook; English Nature: Peterborough, UK, 1992.

68. Michael, N. The Lowland Heathland Management Booklet Version 2.0; English Nature: Peterborough, UK, 1995.

69. Catchpole, C.K.; Phillips, J.F. Territory quality and reproductive success in the Dartford warbler Sylvia undata in Dorset, England. Biol. Conserv. 1992, 61, 209-215.

70. Chapman, S.B.; Rose, R.J.; Clarke, R.T. The behavior of populations of the marsh gentian (Gentiana pneumonanthe): A modelling approach. J. Appl. Ecol. 1989, 26, 1059-1072.

71. Bullock, J.M.; Webb, N.R. Responses to severe fires in heathland mosaics in Southern England. Biol. Conserv. 1995, 73, 207-214.

72. Vega, J.A. Manual de Queimas Prescritas Para Matogueiras de Galicia (In Galician); Xunta de Galicia: Santiago de Compostela, Spain, 2001.

73. Giovannini, G. The Effect of Fire on Soil Quality. In Soil Erosion and Degradation as a Consequence of Forest Fires; Sala, M., Rubio, J.L., Eds.; Geoforma Ediciones: Logroño, Spain, 1994; pp. 15-27.

74. Hobbs, R.J.; Gimingham, C.H. Vegetation, fire and herbivore interactions in heathland. Adv. Ecol. Res. 1987, 16, 87-173.

75. Webb, N.R.; Thomas, J.A. Conserving Insect Habitats in Heathland Biotopes: A Question of Scale. In Largescale Ecology and Conservation Biology; Edwards, P.J., May, R.M., Webb, N.R., Eds.; Blackwell Scientific Publications: Oxford, UK, 1994; pp. 131-157. 
76. Maltby, E.; Legg, C.J.; Proctor, M.C.F. The ecology of severe moorland fire on the North York Moors: Effects of the 1976 fires, and subsequent surface and vegetation development. J. Ecol. 1990, 78, 490-518.

77. Clément, B.; Touffet, J. Plant strategies and secondary succession on Brittany heathlands after severe fire. J. Veget. Sci. 1990, 1, 195-202.

78. Reyes, O.; Casal, M. Regeneration models and plant regenerative types related to the intensity of fire in Atlantic shrubland and woodland species. J. Veget. Sci. 2008, 19, 575-583.

79. ICONA. Primer Inventario Forestal de España. Avance de Resultados (In Spanish); Publicaciones del Ministerio de Agricultura: Madrid, Spain, 1975.

80. ICONA. Segundo Inventario Forestal Nacional. 1986-1995. Galicia. La Coruña (In Spanish); Ministerio de Agricultura, Pesca y Alimentación: Madrid, Spain, 1993.

81. ICONA. Segundo Inventario Forestal Nacional. 1986-1995. Galicia. Lugo (In Spanish); Ministerio de Agricultura, Pesca y Alimentación: Madrid, Spain, 1993.

82. ICONA. Segundo Inventario Forestal Nacional. 1986-1995. Galicia. Orense (In Spanish); Ministerio de Agricultura, Pesca y Alimentación: Madrid, Spain, 1993.

83. ICONA. Segundo Inventario Forestal Nacional. 1986-1995. Galicia. Pontevedra (In Spanish); Ministerio de Agricultura, Pesca y Alimentación: Madrid, Spain, 1993.

84. Ministerio de Medio Ambiente. Tercer Inventario Forestal Nacional. 1997-2006. Galicia. A Coruña (In Spanish); Dirección General de Conservación de la Naturaleza: Madrid, Spain, 2001.

85. Ministerio de Medio Ambiente. Tercer Inventario Forestal Nacional. 1997-2006. Galicia. Lugo (In Spanish); Dirección General de Conservación de la Naturaleza: Madrid, Spain, 2002.

86. Ministerio de Medio Ambiente. Tercer Inventario Forestal Nacional. 1997-2006. Galicia. Ourense (In Spanish); Dirección General de Conservación de la Naturaleza: Madrid, Spain, 2002.

87. Ministerio de Medio Ambiente. Tercer Inventario Forestal Nacional. 1997-2006. Galicia. Pontevedra (In Spanish); Dirección General de Conservación de la Naturaleza: Madrid, Spain, 2002.

88. Ministerio de Medio Ambiente, y Medio Rural y Marino. Cuarto Inventario Forestal Nacional. Galicia (In Spanish); Dirección General de Medio Natural y Política Forestal: Madrid, Spain, 2011.

89. Fahrig, L. Relative effects of habitat loss and fragmentation on population extinction. J. Wildlife Manage. 1997, 61, 603-610.

90. Parker, M.; Mac Nally, R. Habitat loss and the habitat fragmentation threshold: An experimental evaluation of impacts on richness and total abundances using grassland invertebrates. Biol. Conserv. 2002, 105, 217-229.

91. Teixido, A.L.; Quintanilla, L.G.; Carreño, F.; Gutiérrez, D. Impacts of changes in land use and fragmentation patterns on Atlantic coastal forests in northern Spain. J. Environ. Manage. 2010, 91, 897-886.

92. Schumaker, N.H. Using landscape indices to predict habitat connectivity. Ecology 1996, 77, 1210-1225.

93. Canut, J.; García, D.; Obeso, J.R.; Parellada, X. Urogallo Cantábrico (Tetrao Urogallus Cantabricus). In Atlas de las aves Reproductoras de España (In Spanish); Martí, R., del Moral, J.C., Eds.; Ministerio de Medio Ambiente: Madrid, Spain, 2003; pp. 210-211.

94. CREN Limousin. Plan d'actions Landes \& Tourbières. Rapport d'activité 2006 (In French); Conservatoire Régional des Espaces Naturels du Limousin: Le Theil, France, 2007. 
95. Lebrun, J. Appui scientifique et technique pour la restauration de la trame écologique "Réseau lands" dans le PNR Oise-Pays de France: Plan d'actions 2010-2015 (In French); Conservatoire d'Espaces naturels de Picardie/PNR Oise Pays-de-France: Amiens, France, 2010.

96. De Graaf, M.C.C.; Verbeek, P.J.M.; Bobbink, R.; Roelofs, J.G.M. Restoration of species-rich dry heaths: The importance of appropriate soil conditions. Acta Bot. Neerl. 1998, 47, 89-113.

97. Decleer, K. Ecological Restoration in Flanders; Mededelingen van het Instituut voor Natuur- en Bosonderzoek (INBO): Anderlecht, Belgium, 2008.

98. Spencer, D. Tees Valley Lowland Heathland Habitat Action Plan 2009-2013; Redcar \& Cleveland Borough Council: Redcar, UK, 2009.

99. JNCC. Biodiversity: The UK Steering Group Report. Action Plans (Annex F and Annex G); Joint Nature Conservation Committee: London, UK, 1995; Volume 2.

100. Irving, J.A. Warwickshire, Coventry and Solihull Local Biodiversity Action Plan. Lowland Heathland; Warwickshire County Council: Warwick, UK, 2002.

101. Gimingham, C.H. The effects of grazing on the balance between erica cinerea L. and calluna vulgaris (L.) hull. In upland heath, and their morphological responses. J. Ecol. 1949, 37, 100-119.

102. Farrell, L. Heathland Management; Joint Nature Conservation Committee: Peterborough, UK, 1983.

103. McKee, A.M. The Effects of Different Grazing Pressures on Vegetation in the Connemra Uplands. B.Sc. Thesis, University College, Galway, Ireland, 1995.

104. Bullock, J.M.; Pakeman, R.J. Grazing of lowland heath in England: Management methods and their effects on heathland vegetation. Biol. Conserv. 1997, 79, 1-13.

105. Webb, N.R. The traditional management of European heathlands. J. Appl. Ecol. 1998, 35, 987-990.

106. Sedláková, I.; Chytrý, M. Regeneration patterns in a Central European dry heathland: Effects of burning, sod-cutting and cutting. Plant Ecol. 1999, 143, 77-87.

107. Drechsler, M.; Eppink, F.V.; Wätzold, F. Does proactive biodiversity conservation save costs? Biodivers. Conserv. 2011, 20, 1045-1055.

(C) 2013 by the authors; licensee MDPI, Basel, Switzerland. This article is an open access article distributed under the terms and conditions of the Creative Commons Attribution license (http://creativecommons.org/licenses/by/3.0/). 